\title{
NOW READY
}

First English Translation of a Classic

\author{
on \\ Glaciology
}

LOUIS AGASSIZ

STUDIES ON GLACIERS

Preceded by the Discourse of Neuchatel

Translated and edited by ALBERT V. CAROZZI

4to, 214 pages, 18 plates, cloth

220s.

First English Translation of the first book on

\section{Hydrology}

PIERRE PERRAULT

ON THE ORIGIN OF SPRINGS

Translated by AURELE LA ROCQUE

8to, 210 pages, 1 plate, cloth

120 s.

\section{HAFNER PUBLISHING COMPANY}

\section{NEW YORK}

31 E. 10th Street

New York, N.Y.

U.S.A. 10003
LONDON

1 Grange Road

Kingston - upon - Thames

Surrey 


\section{ARITHMETICAL BOOKS}

from the Invention

of Printing to the Present Time

by

AUGUSTUS DE MORGAN (London, 1847)

Reprint 1966 with Introduction by

Prof. A. Rupert Hall $£ 5$ 5s. 0d.

available from

all booksellers or the publishers

Hugh K. Elliott Ltd.

2a Russell Gardens Mews

Kensington

London, W.14

\section{THE NEWCOMEN SOCIETY FOR THE STUDY OF \\ THE HISTORY OF ENGINEERING AND TECHNOLOGY}

Meetings held monthly from October to April. Summer Meeting of four to five days' duration. One-day meetings in the South-East and Midlands.

Transactions, issued annually, contains seven or eight Papers. (A typical volume contained 187 pages, 40 text figures and 51 half-tone illustrations.)

Bulletin of 12 pages issued three times a year.

Subscription: $£ 4$ ( $£ 2$ without Transactions).

Apply for particulars of membership to the Hon. Secretary,

Newcomen Society,

Science Museum, London, S.W.7.

The British Society for the History of Science

Student Membership

A new class of membership has been instituted by the Society, under the title Student membership.

"Students" of the Society must normally be below the age of 25 years and be undergoing a full- or part-time course of education at a school, college or university.

The Annual Subscription for "Students" is $£ 110$ s. 0d. (\$4.50 U.S.).

Student membership entitles the holder to receive Parts of the Society's journal, as these are published, without additional charge, and to receive all the other privileges of Ordinary Membership, except a vote in matters affecting the running of the Society.

Further information about the Society will be found on the inside back cover of this journal. 


\section{Cass Library of Science Classics}

A series of facsimile editions of rare masterpieces of the history and philosophy of science from the Scientific Revolution to modern times.

General Editor: Dr. L. L. Laudan, University College, London.

\section{Titles to be published in 1967}

Charles Babbage Ninth Bridgewater Treatise-A Fragment (2nd ed., $\left.183^{8}\right)$. 9 os

Isaac Barrow The Usefulness of Mathematical Learning (1 734).

Translated by John Kirkby. With a new introduction by M. S. Mahoney. 5 gns

Torbern Bergman A Dissertation on Elective Attractions (1 785). Translated by $T$. Beddoes. With a new introduction by A. M. Duncan. 5 gns

Abraham DeMoivre The Doctrine of Chances: or, A Method of Calculating the Probabilities of Events in Play (2nd revised ed., 1 738). 5 gns

James Edleston, Ed. Correspondence of Sir Isaac Newton and Professor Cotes, including Letters of Other Eminent Men $\left(185^{\circ}\right)$. 6 gns

Johann von Goethe Theory of Colours ( 1840 ). Translated by Charles Eastlake. 6 gns

Robert Hooke Philosophical Experiments and Observations (1 726). Edited by W. Derham. gos

Posthumous Works (1705). Edited by Richard Waller

With a new introduction by T. M. Brown. 12 gns

Christiaan Huygens The Celestial Worlds Discover'd ( 1698). $45^{5}$

Richard Kirwan An Essay on Phlogiston, and the Constitution of Acids (1 789 ). 9os

Antoine Lavoisier Essays, Physical and Chemical (1776). Translated by $\mathrm{T}$. Henry. With a new introduction by Professor D. McKie. 7 gns

J. Clerk Maxwell, Ed. The Electrical Researches of the Honourable Henry Cavendish, F.R.S. (1879). 6 gns

Voltaire The Elements of Sir Isaac Newton's Philosophy ( $173^{8}$ ). Translated by John Hanna. gos

William Whewell Philosophy of the Inductive Sciences (1847) 2 volumes. 12 gns

History of the Inductive Sciences ( $18_{57}$ ) 3 volumes. $15 \mathrm{gns}$

John Wilkins Mathematical and Philosophical Works (1802). 2 volumes in one. 7 gns

Frank Cass \& Co. Ltd 67 Great Russell Street, London W.C.1. 


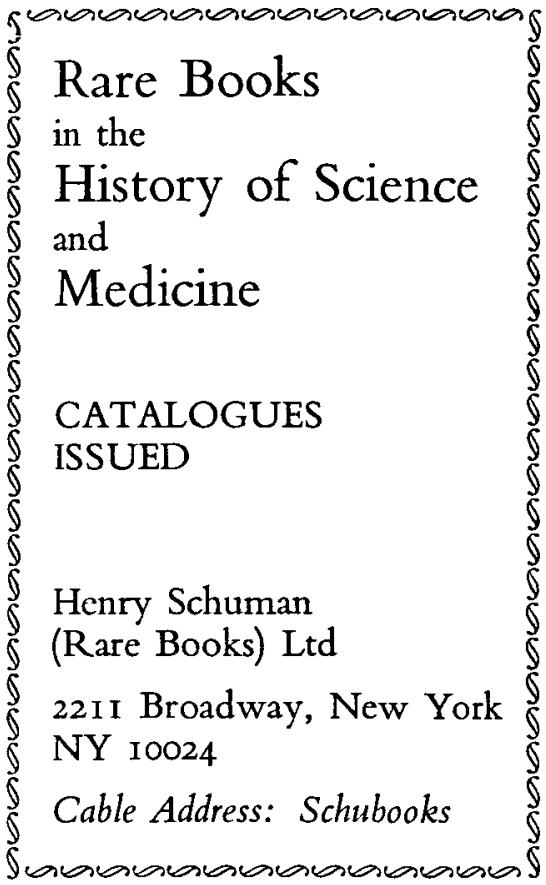

Rare and Important Books in the History of SCIENCE TECHNOLOGY
MEDICINE

(Catalogues available)

Hugh K. Elliott Ltd.

2a Russell Gardens Mews Kensington London, W.14

Telephone: 01-937-2961 Business by post or appointment only

\section{ORIGINS OF MENDELISM} R. C. OLBY

'A useful book which should be widely read by professional biologists and which should be a valuable addition to school and university libraries.' Barrie Burnet, Guardian.

'This scholarly and well-documented study.' Times Literary Supplement.

'Erudite . . . important book.' Times Educational Supplement.

Illustrated 30s.

\section{MICROGRAPHIA ROBERT HOOKE}

A delightful accumulation of ideas and observations, conveying a sense of immediacy and excitement, by the great 17th-century secretary and demonstrator to the Royal Society. Unabridged reprinting of 1665 edition.

38 plates. Dover paperback, 20s.

\section{ELEMENTS OF CHEMISTRY ANTOINE LAVOISIER}

A classic work, with a new Introduction by Douglas McKie, which does for chemistry what Newton's Principia did for physics. 10 tables, 13 double-page plates, 2 charts, 1 foldout. Total of 49 tables. Dover paperback, 28s.

\section{ANTONY VAN LEEUWENHOEK \& HIS 'LITTLE ANIMALS' CLIFFORD DOBELL}

A collection of writings by the father of Protozoology and Bacteriology selected, translated and edited from his printed works, unpublished manuscripts and contemporary records. 32 illustrations. Dover paperback, $18 \mathrm{~s}$.

CONSTABLE 


\section{B.F.P.S.}

The British Journal for the Philosophy of Science

Volume I8, Number 2

\section{CONTENTS}

August, 1967

ARTICLES

MILTON FISK

LAWRENCE SKLAR

A Defence of the Principle of Event Causality Types of Inter-Theoretic Reduction

N. JARDINE

The Concept of Homology in Biology

DISCUSSIONS

GEORGE L. FARRE

I. J. GOOD

Remarks on Swanson's Theory of Models Human and Machine Logic

\section{REVIEWS}

ABSTRACTS

THE BRITISH SOCIETY FOR THE HISTORY OF SCIENCE Future Programme

$$
\text { January - July, } 1968
$$

5 January

WINTER MEETING-LONDON: 10.15 a.m. IMPERIAL College, South Kensington J. A. Chaldecort, EsQ. - 'Josiah Wedgwood's contributions to Pyrometry.'

Also short papers dealing with current research.

March 19 Professor W. F. Grimes, C.B.E.- 'The Development of Archaeological Techniques.'

May 13

Reserved for a Guest Speaker from abroad.

July $5-6$

SUMMER MEETING-LeEdS: The UNIVERSITY Invited papers; short papers dealing with current research. Annual General Meeting; Presidential Address; Annual Dinner.

Enquiries should be addressed to Mr H. G.L. Bevan, Hon. Programme Secretary, Chelsea College of Science, London, S.W.3. 


\section{History of Rocketry and Space Travel}

WERNHER VON BRAUN FREDERICK I. ORDWAY III

Here is the story of how the way to the solar system was opened and how it became possible in our time. No comparable reference work exists which documents rocket flight in such detail, contains as many references, or presents so many fine photographs and illustrations of past and current events.

Wernher von Braun is renowned as the leading rocket engineer in the Western World. Frederick I. Ordway III has been a major contributor to astronomical reference works.

206 pages of illustrations, charts and diagrams, 32 in colour. $84 /-$

\section{The Early Birds}

\section{ARCH WHITEHOUSE}

This is the dramatic story of aviation's momentous first fifteen years-from the Wright's twelve-second flight to the deadly war-time air battles of 1914-1918. Arch Whitehouse, who was one of the air aces of World War I and whose own experience spans nearly the entire modern history of powered flight, describes the colourful careers of the men who joined in the race to rival the birds.

31 half-tones.

$52 /-$

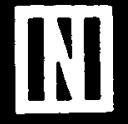

NELSON

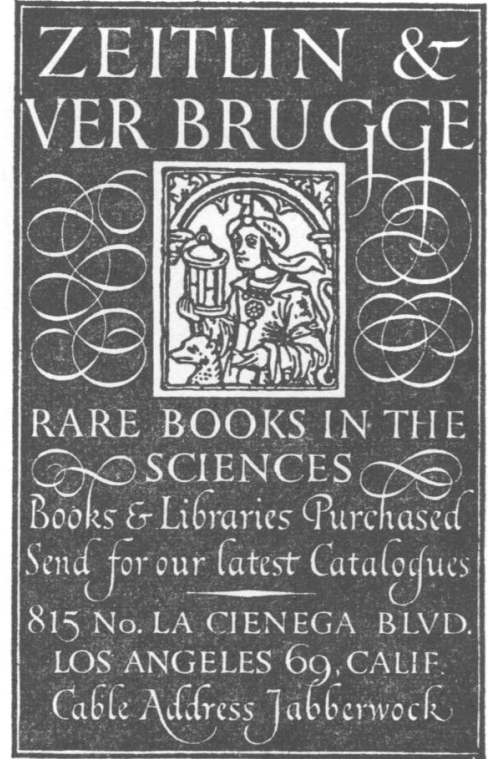

BERNARD

\section{QUARITCH}

\section{LIMITED}

Antiquarian Booksellers

since 1847

RARE BOOKS on

MEDICINE, NATURAL

HISTORY AND OTHER SCIENCES

Catalogues issued

II GRAFTON STREET NEW BOND STREET

W.I

HYD 0022 


\section{THE BRITISH SOCIETY FOR THE HISTORY OF SCIENCE}

THE objects of the Society are to further the study of the history of science, by holding meetings for the reading and discussion of papers, and by facilitating the publication of relevant material.

The British Fournal for the History of Science is the official organ of the Society.

Meetings are held in the Science Museum, Exhibition Road, South Kensington, London, S.W.7, usually in October, November, March and May. In addition a Winter Meeting is held in January and a Summer Meeting in June; neither of these meetings is necessarily held in London.

Membership is open to all persons approved by the Council of the Society, and elected at an Ordinary Meeting. The annual subscription is at present $£_{2}$ Ios. (for Students $£_{1}$ Ios.) and includes a free issue of the Society's Journal, which appears in June and December each year.

Those who wish to join the Society should write to the Hon. Secretary, Mr. J. A. Chaldecott, Science Museum, South Kensington, London, S.W.7.

Papers for inclusion in the Journal should be submitted to the Hon. Editor, Dr. M. P. Crosland, Department of Philosophy, The University, Leeds 2, from whom instructions may be obtained concerning the presentation and documentation of papers. All communications on editorial matters, and books for review, should be addressed to the Hon. Editor.

Particulars regarding advertising in the Journal may be obtained from the Hon. Treasurer, Mr. D. Chilton, Science Museum, South Kensington, London, S.W.7.

The British Fournal for the History of Science is published by the Society. Four parts constitute one Volume; each part contains approximately 96 pages. The cover of each issue has a consecutive number for ease of collation in subsequent binding, e.g. No. 16 will be numbered: Vol. Iv Part Iv No. 16, and No. 17 will be: Vol. v Part r No. I7.

Order Forms, with lists of contents of Parts already published, are obtainable from the Hon. Publications Secretary, Dr. F. D. North, 39 Wellington Square, Oxford, to whom Orders for the Journal should be sent.

Whole Cloth Binding Cases lettered in Gold on spine and particulars of binding costs may be obtained from Headley Brothers Ltd., Invicta Press, AsHFORD, KENT. 


\section{THE BRITISH JOURNAL FOR THE HISTORY OF SCIENCE}

Volume III Part iv December 1967 No. 12

Hull, David L.-The Metaphysics of Evolution

Keller, A. G.-Pneumatics, Automata and the

Vacuum in the Work of Giambattista Aleotti

Wells, George A.-Goethe and the Intermaxillary Bone

MaCormmach, Russell.-J. J. Thompson and the Structure of Light

Notes and Communications:

Pacey, A. J. and Fisher, S. J.-Daniel Bernoulli and the Vis Viva of Compressed Air

ForBes, ERIC G.-The Bicentenary of the Nautical Almanac ( 1767 )

Essay Review

395-396

Book Reviews

$397-408$

Books Received

$409-410$

Notes on Contributors

Report of Council and Financial Statement

PUBLISHED BY THE BRITISH SOCIETY FOR THE HISTORY OF SCIENCE

Registered Office: Science Museum, South Kensington, London, S.W.7

Brit. J. Hist. Sci. 3 no. 12. Price $f_{1}$ Is. Free to Members of the Society. Published December 1967 